\title{
ANALISIS PERJANJIAN KERJASAMA PENGELOLAAN PARIWISATA ULUN DANU BERATAN DESA PAKRAMAN CANDI KUNING KABUPATEN TABANAN
}

\author{
I Gusti Putu Arya Gunawan \\ Program Magister Kenotariatan Fakultas Hukum Universitas Brawijaya \\ JI. MT. Haryono No 169; Malang; 65145; Indonesia; (0341) 553898 \\ gung_david@yahoo.co.id
}

\begin{abstract}
This writing aims to analyze the cooperation agreement of Ulun Danu Beratan tourism management between the Local Government of Tabanan Regency with Pakraman Candi Kuning Village. With the formulation of issues such as whether the form of cooperation agreement has met the requirements of the agreement law, and Why cooperation agreements reflect more justice than the cooperation agreement of tourism management Tanah Lot. The research method used is the normative legal method, the approach used is the approach of legislation and concept approach. The results of this study note that the agreement is in accordance with the requirements of the validity of an agreement and in accordance with Government Regulation No. 50 of 2007 on Procedures Implementation of Regional Cooperation. While the form of the agreement is made with the agreement under the hands. The cooperation agreement is contradictory to Article 179 paragraph (4) of Regulation of the Minister of Home Affairs Number 19 of 2016 concerning Guidance on Management of Regional Property, the cooperation agreement must be made by notarial deed, so that the cooperation agreement has strong evidentiary power in case of dispute in court and the agreement reflects justice compared to the Tanah Lot tourism cooperation agreement.
\end{abstract}

Keywords: Cooperation Agreement, Justice, Tourism Management.

\begin{abstract}
Abstrak
Penulisan ini bertujuan untuk menganalisis perjanjian kerjasama pengelolaan pariwisata Ulun Danu Beratan antara Pemerintah Daerah Kabupaten Tabanan dengan Desa Pakraman Candi Kuning. Dengan rumusan masalah diantaranya A pakah bentuk perjanjian kerjasama telah memenuhi syarat dalam hukum perjanjian, serta Mengapa perjanjian kerjasama lebih mencerminkan keadilan dibandingkan perjanjian kerjasama pengelolaan pariwisata Tanah Lot. Metode penelitian yang digunakan adalah metode hukum normatif dan pendekatan yang digunakan adalah pendekatan perundang-undangan dan pendekatan konsep. Berdasarkan hasil penelitian ini diketahui bahwa perjanjian tersebut sudah sesuai dengan syarat sahnya suatu perjanjian dan sesuai dengan Peraturan Pemerintah Nomor 50 Tahun 2007 tentang Tata Cara Pelaksanaan Kerjasama Daerah. Sedangkan bentuk dari perjanjian tersebut dibuat dengan bentuk perjanjian dibawah tangan. Perjanjian kerjasama tersebut bertentangan dengan Pasal 179 ayat (4) Peraturan Menteri Dalam Negeri Nomor 19 tahun 2016 tentang Pedoman Pengelolaan Barang Milik Daerah bahwa perjanjian kerjasama harus dibuat dengan Akta Notaris, sehingga dari perjanjian kerjasama tersebut mempunyai kekuatan pembuktian yang kuat apabila terjadi sengketa di pengadilan dan perjanjian tersebut sudah mencerminkan keadilan dibandingkan perjanjian kerjasama pariwisata Tanah Lot.
\end{abstract}

Kata kunci: Keadilan, Pengelolaan Pariwisata, Perjanjian Kerjasama 


\section{Jurnal Cakrawala Hukum}

Vol.8, No.2 Desember 2017: 129-138

\section{Pendahuluan}

Kegiatan pariwisata di Provinsi Bali membawa dampak yang cukup luas terhadap perkembangan perekonomian. Melalui pembangunan industri pariwisata, banyak lapangan kerja atau usaha yang bisa dikembangkan, seperti usaha perdagangan, hotel, restoran, sektor industri dan jasa lainnya. Masing-masing sektor yang terlibat untuk pengembangan pariwisata, akan mampu meningkatkan terciptanya kesempatan kerja yang lebih luas dan sekaligus meningkatkan pendapatan masyarakat yang terlibat di dalamnya.

Menurut Pasal 1 angka 55, 56 dan 57 Peraturan Daerah Provinsi Bali Nomor 16 Tahun 2009 Tentang Rencana Tata Ruang Wilayah, menyebutkan Pasal 55 Kawasan Pariwisata adalah kawasan strategis pariwisata yang berada dalam geografis satu atau lebih wilayah administrasi desa/ kelurahan yang di dalamnya terdapat potensi daya tarik wisata, aksesibilitas yang tinggi, ketersediaan fasilitas umum dan fasilitas pariwisata serta aktivitas sosial budaya masyarakat yang saling mendukung dalam perwujudan kepariwisataan. Sedangkan Pasal 56 dinyatakan bahwa Kawasan Daya Tarik Wisata Khusus, yang selanjutnya disebut KDTWK, adalah kawasan strategis pariwisata yang berada dalam geografis satu atau lebih wilayah administrasi desa/ kelurahan yang di dalamnya terdapat potensi daya tarik wisata, aksesibilitas yang tinggi, ketersediaan fasilitas umum dan fasilitas pariwisata secara terbatas serta aktivitas sosial budaya masyarakat yang saling mendukung dalam perwujudan kepariwisataan, namun pengembangannya sangat dibatasi untuk lebih diarahkan kepada upaya pelestarian budaya dan lingkungan hidup.

Adapun pasal 57 dinyatakan bahwa Daya Tarik Wisata, yang selanjutnya disebut DTW, adalah segala sesuatu yang memiliki keunikan, keindahan, dan nilai yang berupa keanekaragaman kekayaan alam, budaya, hasil buatan manusia serta aktivitas sosial budaya masyarakat yang menjadi sasaran atau tujuan kunjungan wisatawan, yang dapat berupa kawasan/ hamparan, wilayah desa/ kelurahan, masa bangunan, bangun-bangunan dan lingkungan sekitarnya, jalur wisata yang lokasinya tersebar di wilayah kabupaten/kota.

Bali disamakan dengan kebudayaan dan adat yang dimiliki oleh masyarakatnya. Salah satu utama penyangga kebudayaan di Bali, yaitu Desa Pakraman, yang sebelumnya disebut Desa Adat. Desa dalam Pasal 1 angka 1 Undang-Undang Republik Indonesia Nomor 6 Tahun 2014 tentang Desa adalah suatu kesatuan masyarakat hukum yang memiliki batas wilayah yang berwenang untuk mengatur dan mengurus urusan pemerintahan sendiri, memiliki kepentingan setempat berdasarkan prakarsa masyarakat itu sendiri, memiliki hak asal usul, serta memiliki hak tradisional yang diakui dan dihormati dalam sistem pemerintahan Negara Kesatuan Republik Indonesia.

Desa Pakraman di Bali adalah satu masyarakat hukum yang memiliki otonomi asli, yaitu kewenangan untuk mengatur atau mengurus rumah tangganya sendiri, kekuasaan mana terlahir dari desa itu sendiri, tidak dari kekuasaan lain yang lebih tinggi, apabila otonomi dari Desa Pakraman dijabarkan lebih lanjut dapat dilihat bahwa setidaktidaknya ada tiga jenis kekuasaan yang melekat pada otonomi tersebut yaitu; Kekuasaan untuk menetapkan aturan-aturan hukum yang mesti diperhatikan dan ditaati oleh setiap bagian dari masyarakat tersebut, Kekuasaan untuk menyelenggarakan tata kehidupan masyarakat dalam rangka mewujudkan kesejahteraan warga, Kekuasaan untuk menyelesaikan sengketa yang terjadi di kalangan warga (Griadhi, 1977).

Kabupaten Tabanan adalah salah satu dari beberapa kabupaten/kota yang ada di Provinsi Bali yang terletak di sebelah barat Kota Denpasar. Kabupaten Tabanan memiliki objek wisata seperti, Tanah Lot, Ulun Danu Beratan, Alas Kedaton, Jati Luwih, Pantai Kelating dan masih banyak objek wisata lainya di Kabupaten Tabanan. Sebagai dasar pengelolaan objek dan daya tarik wisata, yang di- 
lakukan oleh Pemerintah Daerah Kabupaten Tabanan mengeluarkan Surat Perjanjian Kerjasama Nomor 2 Tahun 2011 Tentang Kerjasama Pengelolaan Daya Tarik Wisata Ulun Danu Beratan antara Pemerintah Daerah Kabupaten Tabanan dengan Desa Pakraman Candi Kuning yang diwakili oleh Satakan (Satakan merupakan sistem masyarakat daerah yang memiliki ciri dan struktur khusus yang dijadikan pedoman dalam pengelolaan area suci (Pura) besar yang ada di suatu wilayah Ulun Danu Beratan) dan PT. Rekreasi Air Beratan Indah.

Perjanjian kerjasama pengelolaan pariwisata tersebut untuk mengetahui antara hak dan kewajiban yang harus dilakukan para pihak, sehingga apa yang menjadi isi perjanjian baik itu hak dan kewajibannya dapat dijalankan dengan baik dan memiliki kedudukan yang sama tanpa merugikan salah satu pihak, sehingga terjadi keadilan terutama bagi pihak kedua yang mewakili masyarakat dan untuk mengetahui bentuk dari perjanjian kerjasama pengelolaan pariwisata Ulun Danu Beratan telah memenuhi syarat dalam hukum perjanjian, baik dalam hal perjanjian secara umum maupun secara khusus mengenai adanya perjanjian pengelolaan pariwisata.

Perjanjian kerjasama pengelolaan pariwisata yang dilakukan oleh Pemerintah Kabupaten Tabanan dengan Desa Pakraman Candi Kuning, tentang pengaturan pembagian hasil, Pura Kahyangan Jagat Ulun Danu Beratan, memperoleh pembagian hasil lebih besar dari Pemerintah Daerah Kabupaten Tabanan, dari perjanjian kerjasama tersebut sudah mencerminkan keadilan bagi Desa Pakraman Candi Kuning selaku pihak yang menjaga kelestarian dan kesucian dari daerah daya tarik wisata Ulun Danu Beratan dan Pura Kahyangan Jagat Ulun Danu Beratan.

Berbeda dengan perjanjian kerjasama antara Pemerintah Daerah Kabupaten Tabanan dengan Desa Pakraman Beraban Nomor: 358/ DPBRB/ XI/ 2011 tentang Pengelolaan Daya Tarik Wisata Tanah Lot, yang belum mencerminkan keadilan dari pembagian hasil, sehingga merugikan bagi Desa Pakraman Beraban yang memiliki tugas dan kewajiban untuk menjaga kelestarian dan kesucian dari daerah tujuan wisata Tanah Lot dan Pura Luhur Tanah Lot.

Berdasarkan dari latar belakang di atas, tujuan penelitian ini untuk melakukan analisa dan penelitian terhadap Perjanjian Kerjasama Pengelolaan Pariwisata Ulun Danu Beratan Antara Pemerintah Daerah Kabupaten Tabanan Dengan Desa Pakraman Candi Kuning. Dengan rumusan masalah diantaranya Apakah bentuk perjanjian kerjasama pengelolaan pariwisata Ulun Danu Beratan antara Pemerintah Daerah Kabupaten Tabanan dengan Desa Pakraman Candi Kuning telah memenuhi syarat dalam hukum perjanjian, serta Mengapa perjanjian kerjasama pengelolaan pariwisata Ulun Danu Beratan lebih mencerminkan keadilan dibandingkan perjanjian kerjasama pengelolaan pariwisata Tanah Lot.

\section{Metode Penelitian}

Penelitian yang digunakan adalah penelitian hukum normatif (Marzuki, 2007). Penelitian hukum normatif disebut juga penelitian hukum doktrinal, disebut juga penelitian perpustakaan atau studi dokumen (Waluyo, 2002). Penelitian hukum normatif adalah pemecahan masalah yang didasarkan pada peraturan perundang-undangan dan literatur-literatur yang berkaitan dengan permasalahan yang dibahas beranjak dari adanya kesenjangan dalam norma atau asas hukum, yang memiliki ciri dengan menggunakan landasan teoritis dan bahan hukum yang terdiri atas bahan hukum primer dan bahan hukum sekunder. Landasan teoritis yang digunakan merupakan peraturan perundang-undangan, norma-norma, teori-teori maupun perjanjian yang sesuai dengan permasalahan yang diangkat. Penelitian hukum jenis ini, sering dikonsepkan sebagai apa yang tertulis dalam peraturan perundang-undangan (law in books) atau hukum dikonsepkan sebagai kaidah atau norma 
yang merupakan patokan berprilaku manusia yang dianggap pantas.

Pendekatan yang digunakan didalam penelitian hukum ini adalah pendekatan perundangundangan (statue approach) pendekatan konsep (conseptual approach) untuk menghasilkan konsep perbaikan, pendapat ahli dari literatur, jurnal, koran, dan artikel dari internet sebagai bahan pendekatan untuk menganalisa. Melalui pendekatan ini maka penulis menggali bahan-bahan hukum, yang baik dipublikasikan maupun yang tidak dipublikasikan dan untuk selanjutnya menyimpulkan permasalahan tersebut berdasarkan data-data yang diperoleh. Pendekatan ini dilakukan dengan jalan menelusuri bahan-bahan pustaka, baik literatul, Undang-undang, Peraturan-peraturan yang dikeluarkan oleh Pemerintah dan teori-teori yang ada.

Sumber bahan hukum yang dipergunakan dalam penelitian ini dapat dibedakan dalam 3 (tiga) kelompok yaitu: Bahan hukum primer adalah data utama yang digunakan untuk mengkaji permasalahan. Menurut Peter Marzuki, bahan hukum primer terdiri dari perundang-undangan, catatan-catatan resmi atau risalah pembuatan perundang-undangan dan putusan-putusan hakim (Marzuki, 2005). Bahan hukum yang digunakan dalam penelitian ini adalah, Undang-undang Nomor 23 Tahun 2014 tentang Pemerintahan Daerah, Undang-undang Nomor 10 Tahun 2009 tentang Kepariwisataan, Undang-undang Desa Rencana Tata Ruang Wilayah (RTRW) Kabupaten Tabanan tahun 2012-2032, Rencana Pembangunan Jangka Menengah Daerah (RPJMD) Kabupaten Tabanan 2016-2021, Perjanjian kerjasama Nomor: 2 Tahun 2011 tentang pengelolaan daya tarik wisata antara Pemerintah Daerah Kabupaten Tabanan dengan Satakan Ulun Danu Beratan dan PT. Rekreasi Air Beratan Indah Nomor: 2 tahun 2011 dan Perjanjian Kerjasama Nomor 358/ DPBRB/XI/ 2011 tentang pengelolaan daya tarik Tanah Lot.
Bahan hukum sekunder adalah data yang diperoleh dari studi pustaka atas berbagai penelitian yang ada sebelumnya yang dapat berbentuk laporan penelitian seperti, skripsi dan buku-buku literatur serta semua komponen tersebut (Muhamad, 2004). Dalam bahan hukum sekunder terdapat informasi atau kajian yang relevan dengan penelitian ini, berupa bahan hukum yang terdiri dari buku-buku kepustakaan, jurnal hukum, karya tulis ilmiah dan beberapa sumber dari internet. Bahan hukum tersier adalah bahan hukum yang memberikan pentujuk, penunjang ataupun penjelasan terhadap data hukum primer dan sekunder, contohnya kamus, ensiklopedia, indeks kualitatif dan seterusnya. (Soekanto \& Mamuji, 2006). Menurut Soerjono dan Sri Mamuji (2006) menyatakan bahwa, dalam suatu penelitian ini mengandalkan pada penggunaan dari bahan hukum primer bahan hukum yang mengikat, bahan hukum sekunder yang memberikan penjelasan mengenai bahan hukum primer dan bahan hukum tersier bahan hukum yang memberikan suatu petunjuk, penjelasan terhadap bahan hukum primer dan sekunder.

\section{Pembahasan}

\section{A. Bentuk Perjanjian Kerjasama Pengelolaan Pariwisata Ulun Danu Beratan Antara Pemerintah Daerah Kabupaten Tabanan Dengan Desa Pakraman Candi Kuning Telah Memenuhi Syarat dalam Hukum Perjanjian}

Perjanjian kerjasama pengelolaan parwisata Ulun Danu Beratan antara Pemerintah Daerah Kabupaten Tabanan dengan Desa Pakraman Candi Kuning memiliki bentuk perjanjian baku. Menurut Hondius, perjanjian baku adalah konsep-konsep atau janji-janji tertulis, disusun tanpa membicarakan isinya dan lazimnya, dituangkan ke dalam perjanjian yang sifatnya tertentu (Sukarmi, 2008).

Perjanjian tersebut dikatakan perjanjian baku karena dalam perjanjian telah dibuat dengan 
bentuk perjanjian kerjasama yang berdasarkan pada Undang-undang Tata Cara Pelaksanaan Kerjasama Daerah, meskipun perjanjian kerjasama pengelolaan pariwisata Ulun Danu Beratan antara Pemerintah Daerah Kabupaten Tabanan dengan Desa Pakraman Candi Kuning merupakan perjanjian baku yang segala aturan mengenai tata cara pembuatannya telah mengacu pada peraturan perundang-undangan, namun tetap harus menjunjung asas keadilan, persamaan kedudukan dan saling menguntungkan bagi para pihak yang melakukan perjanjian.

Sesuai dengan pengertian perjanjian baku, dimana seluruh klausul-klausulnya dibakukan oleh pemakainya dan pihak yang lain pada dasarnya tidak mempunyai peluang untuk merundingkan atau meminta perubahan. Bentuk dan isi dari Perjanjian Kerjasama Pengelolaan Pariwisata Ulun Danu Beratan Antara Pemerintah Daerah Kabupaten Tabanan Dengan Desa Pakraman Candi Kuning sesuai dengan perjanjian baku, banyak kemungkinan dalam hal ini Pemerintah Daerah Kabupaten Tabanan merancang format dari bentuk dan isi perjanjian kerjasama tersebut untuk menambahkan klausul eksonerasi. Klausul eksonerasi adalah penambahan klausul-klausul yang menguntungkan, merugikan bahkan menghapus beban-beban kewajiban yang seharusnya menjadi beban pihak yang membuat perjanjian. Klausul eksonerasi tidak sepenuhnya dilarang, karena klausul eksonerasi juga berdasarkan kesepakatan kedua belah pihak yang tercantum dalam Pasal 1320 ayat (1) Kitab Undangundang Hukum Perdata (selanjutnya disebut KUHPerdata), yang dilarang klausul eksonerasi yang tergolong perbuatan penyalahgunan keadaan.

Perjanjian baku harus dipandang sebagai suatu perjanjian atau kontrak yang dipersiapkan sebelumnya untuk digunakan secara umum dan berulang-ulang oleh salah satu pihak dan dalam kenyataan digunakan tanpa negosiasi dengan pihak lain. Perjanjian kerjasama pengelolaan Pariwisata Ulun Danu Beratan antara Pemerintah
Daerah Kabupaten Tabanan dengan Desa Pakraman Candi Kuning, dikaitkan dengan sahnya suatu perjanjian sesuai dengan Pasal 1320 KUHPerdata, terdapat empat syarat sahnya perjanjian; Sepakat mereka yang mengikatkan dirinya, Kecakapan untuk membuat suatu perikatan, Suatu objek tertentu, Suatu sebab yang halal.

Perjanjian yang belum memenuhi persyaratan dalam Pasal 1320 KUHPerdata, maka kontrak dengan klausul baku tetap sah, hal tersebut jika dikaitkan dengan perjanjian kerjasama pengelolaan pariwisata Ulun Danu Beratan antara Pemerintah Kabupaten Tabanan dengan Desa Pakraman Candi Kuning, adalah perjanjian yang sah secara ketentuan hukum.

Perjanjian kerjasama pengelolaan pariwisata Ulun Danu Beratan antara Pemerintah Daerah Kabupaten Tabanan dengan Desa Pakraman Candi Kuning, termasuk perjanjian dalam bentuk baku, perjanjian tersebut juga dibuat dibawah tangan. Perjanjian yang dibuat dibawah tangan adalah perjanjian yang dimasukan oleh para pihak sebagai alat bukti, tetapi tidak dibuat oleh atau dihadapan pejabat umum (Situmorang, 1993). Perjanjian yang dibuat dibawah tangan; Bentuknya bebas, Pembuatanya tidak harus dihadapan pejabat umum, Tetap mempunyai kekuatan pembuktian selama tidak disangkal oleh pembuatnya, artinya bahwa isi dari akta tersebut tidak perlu dibuktikan lagi kecuali ada yang bisa membuktikan sebaliknya (menyangkal isinya). Hal tersebut harus dibuktikan, maka pembuktian tersebut harus dilengkapi juga dengan saksi-saksi dan bukti lainya. Oleh karena itu, biasanya dalam akta dibawah tangan, sebaiknya dimasukan 2 orang saksi yang sudah dewasa untuk memperkuat pembuktian (Situmorang, 1993).

\section{B. Kekuatan Perjanjian Kerjasama yang Dibuat Dibawah Tangan}

Bentuk perjanjian sangat erat kaitanya dengan asas konsensualisme yang dikenal dalam 
KUHPerdata. Asas konsensualisme dalam Pasal 1320 ayat (1) KUHPerdata lebih memfokuskan syarat pada kesepakatan para pihak, yaitu bertemunya antara penawaran dan penerimaan. Bentuk perjanjian dapat dibedakan menjadi dua macam yaitu perjanjian tertulis dan perjanjian lisan.

Perjanjian kerjasama pengelolaan pariwisata Ulun Danu Beratan antara Pemerintah Daerah Kabupaten Tabanan dengan Desa Pakraman Candi Kuning, bertentangan dengan Peraturan Menteri dalam Negeri Nomor 19 Tahun 2016 tentang pedoman Pengelolaan Barang Milik Daerah yang dibuat dengan perjanjian dibawah tangan, yang menurut Pasal 179 ayat (4) Peraturan Menteri dalam Negeri Nomor 19 Tahun 2016 tentang pedoman Pengelolaan Barang Milik Daerah, perjanjian kerjasama pengelolaan pariwisata Ulun Danu Beratan antara Pemerintah Daerah Kabupaten Tabanan dengan Desa Pakraman Candi Kuning, harus dibuat dengan Akta Notaris, sehingga kekuatan pembuktian dari perjanjian yang dibuat dibawah tangan tersebut menjadi tidak sempurna.

Perjanjian kerjasama yang dibuat dibawah tangan maupun yang dibuat dengan akta otentik harus memenuhi rumusan mengenai sahnya suatu perjanjian berdasarkan Pasal 1320 KUHPerdata dan secara materil mengikat para pihak yang membuatnya (KUHPerdata, Pasal 1338). Sebagai suatu perjanjian yang harus ditepati oleh para pihak (asas pactasunt servanda).

\section{a. Perjanjian Kerjasama Pengelolaan Pariwisata Ulun Danu Beratan Yang Mencerminkan Keadilan}

Perjanjian kerjasama pengelolaan pariwisata Ulun Danu Beratan menimbulkan suatu hak dan kewajiban dari pihak yang membuatnya. Hak merupakan suatu tuntutan atau dapat dibuat oleh atau atas nama seseorang individu atau kelompok pada beberapa kodisi atau kekuasaan. Hak merupakan segala sesuatu yang harus didapatkan oleh setiap orang yang terjadi sejak lahir dan waktu sebelum lahir. Dengan hak yang dimiliki seseorang dapat mewujudkan apa yang menjadi keinginan dan kepentingan dari seseorang. Hak yang terdapat dalam suatu perjanjian kerjasama adalah hak nisbi atau hak relatif yang memberikan wewenang kepada seseorang tertentu atau beberapa orang lain tertentu memberikan sesuatu (Purba, 2006).

Kewajiban merupakan suatu pemenuhan seluruh kepentingan asasi yang diaku dan dilindungi oleh hukum. Hak dan kewajiban merupakan suatu konsep penting dalam yurisprudensi dan etika yang sama dimana hak berisi tuntutan dan kondisi baik. Terdapat hak pada seseorang bahwa seseorang memiliki suatu keistimewaan tersebut adanya suatu kewajiban pada seseorang berarti bahwa diminta daripadanya suatu sikap atau tindakan yang sesuai dengan keistimewaan yang ada pada orang lain (Hujibers, 1995). Perjanjian kerjasama pengelolaan pariwisata Ulun Danu Beratan antara Pemerintah Daerah Kabupaten Tabanan dengan Desa Pakraman Candi Kuning, terdapat suatu keseimbangan antara hak dan kewajiban yang diperoleh Desa Pakraman Candi Kuning, keseimbangan tersebut dimiliki oleh Desa Pakraman Candi Kuning berdasarkan Pasal 2 huruf c Peraturan Pemerintah Nomor 50 tahun 2007 tentang Tata Cara Pelaksanaan Kerjasama Daerah menyatakan: "kerjasama daerah dilakukan dengan prinsip sinergi" sinergi yang dimaksud dalam Pasal 2 huruf c adalah suatu upaya untuk mewujudkan keharmonisan antara Pemerintah, masyarakat dan pihak swasta untuk melakukan kerjasama demi mewujudkan kesejahteraan dalam masyarakat.

Pihak dalam perjanjian kerjasama pengelolaan pariwisata Ulun Danu Beratan antara Pemerintah Daerah Kabupaten Tabanan dengan Desa Pakraman Candi Kuning memiliki keseimbang dalam menentukan hak dan kewajiban dari para pihak. Keseimbangan yang diperoleh dari para pihak dalam perjanjian kerjasama tersebut, berasal dari kesepakatan yang ditentukan sebelumnya 
dengan memenuhi unsur-unsur keadilan berlandaskan KUHPerdata dalam Pasal 1320 dan Pasal 1338.

Perjanjian Kerjasama Pengelolaan Pariwisata Ulun Danu Beratan Nomor 2 Tahun 2011, pihak yang terkait kesepakatan dengan latar belakang (Pasal 1), pengelolaan (Pasal 2), subyek perjanjian (Pasal 3), obyek perjanjian (Pasal 4), organisasi (Pasal 5), pengurus (Pasal 6), jangka waktu (Pasal 7), pendapatan (Pasal 8), biaya (Pasal 9), pembagian hasil (Pasal 10) keadaan memaksa/force majeur (Pasal 11), perjanjian batal (Pasal 12), perselisihan (Pasal 13) dan penutup (Pasal 14).

Pelaksanaan perjanjian kerjasama dan hak dari pengelolaan Ulun Danu Beratan, sudah mencerminkan keadilan yang tercermin pada pembagian hasil yang diperoleh Desa Pakraman Candi Kuning yang memiliki tugas untuk mengembangkan dan mengawasi pengelolaan daya tarik wisata Ulun Danu Beratan, yang dapat dilihat dalam, Pasal 10 tentang Pembagian Hasil. Bahwa dari hasil pendapatan bruto setelah dikurangi dengan biaya-biaya, maka Para Pihak sepakat pembagian hasil pengelolaan Daya Tarik Wisata Ulun Danu Beratan adalah sebagai berikut:

1) Pura Khayangan Jagat Ulun Danu Beratan Sebesar $60 \%$ (enam puluh persen);

2) Pemerintah Kabupaten Tabanan sebesar 25\% (dua puluh lima persen);

3) PT. Rekreasi Air Beratan Indah sebesar 3\% (tiga persen);

4) Operasional Badan Pengelola sebesar 9\% (sembilan persen); dan

5) Satakan Candi Kuning sebesar 3\% (tiga persen).

\section{b. Perjanjian Kerjasama Pengelolaan Pariwisata Tanah Lot}

Perjanjian menjadi suatu yang penting seiring dengan pertumbuhan dan perkembangan ekonomi saat ini. Perjanjian Nomor 358/DPBRB/XI/2011 tentang kerjasama pengelolaan pariwisata Tanah
Lot antara Pemerintah Daerah Kabupaten Tabanan dengan Desa Pakraman Beraban, telah memenuhi syarat perjanjian. Syarat-syarat mengenai perjanjian yang telah dijelaskan, sesuai dengan ketentuan Pasal 1320 KUHPerdata dan Peraturan Pemerintah tentang Tata Cara Pelaksanaan Kerjasama Daerah. Pasal 1320 KUHPerdata terdapat 4 (empat) syarat fundamental yang harus dipenuhi sehingga perjanjian dinyatakan sah.

Sesuai dengan Perjanjian Nomor 358/DPBRB/ XI/2011 yang dibuat antara Pemerintah Daerah Kabupaten Tabanan dengan Desa Pakraman Beraban, menyatakan para pihak telah sepakat untuk mengikat diri yang sesuai dengan syarat perjanjian bagian pertama, mengenai kecakapan untuk membuat perjanjian. Pemerintah Daerah Kabupaten Tabanan dengan Desa Pakraman Beraban yang sepakat membuat perjanjian telah memenuhi syarat sebagai subyek hukum yang telah memenuhi syarat perjanjian pada bagian kedua. Syarat perjanjian pada bagian ketiga mengenai suatu hal tertentu, sesuai dengan isi perjanjian telah dijelaskan yang menjadi objek/prestasi yaitu mengenai pengelolaan objek wisata Tanah Lot.

Prestasi yang terdiri atas memberikan sesuatu, berbuat sesuatu dan tidak berbuat sesuatu (Pasal 1234 KUHPerdata). Bagian keempat tentang suatu sebab yang halal, dijelaskan sebab yang dibenarkan oleh undang-undang, ketertiban umum, kebiasaan, kepatutan dan kesusilaan. Dalam perjanjian kerjasama pengelolaan pariwisata Tanah Lot antara Pemerintah Daerah Kabupaten Tabanan dengan Desa Pakraman Beraban belum mencerminkan keadilan dilihat dari isi perjanjian tersebut mengenai hak dan kewajiban dari masingmasing pihak yang terlibat dalam perjanjian kerjasama pengelolaan tersebut.

Perjanjian kerjasama pengelolaan pariwisata Tanah Lot antara Pemerintah Daerah Kabupaten Tabanan dengan Desa Pakraman Beraban, belum terjadi suatu keseimbangan antara hak dan kewajiban yang diperoleh Desa Pakraman Beraban, 
ketidak seimbangan tersebut diterima oleh Desa Pakraman Beraban. Pemerintah Daerah Kabupaten Tabanan sebagai pihak yang memiliki kewenangan untuk dapat melakukan kerjasama yang berdasarkan Pasal 2 huruf c Peraturan Pemerintah Nomor 50 tahun 2007 tentang Tata Cara Pelaksanaan Kerjasama Daerah menyatakan: "kerjasama daerah dilakukan dengan prinsip sinergi" sinergi yang dimaksud dalam Pasal 2 huruf c adalah suatu upaya untuk mewujudkan keharmonisan antara Pemerintah, masyarakat dan pihak swasta untuk melakukan kerjasama demi mewujudkan kesejahteraan dalam masyarakat.

Isi perjanjian kerjasama pengelolaan tersebut seharusnya tidak merugikan pihak dari Desa Pakraman Beraban, namun belum terjadi tanggung jawab untuk ikut memelihara dan membantu kelangsungan pembangunan infrastruktur sebagai timbal balik dari pembagian hasil yang diperoleh Pemerintah Daerah Kabupaten Tabanan dari pengelolaan objek wisata Tanah Lot. Keseimbangan merupakan suatu keadaan pembagian beban di kedua sisi berada dalam keadaan seimbang (Budiono, 2006).

Konsep keseimbangan dituangkan menjadi suatu asas hukum dalam perjanjian yakni asas keseimbangan. Asas hukum berfungsi sebagai pondasi yang memberikan arah tujuan serta penilaian fundamental, mengandung nilai-nilai dan tuntutan-tuntutan etis (Raharjo, 2000). Para pihak dalam perjanjian kerjasama pengelolaan pariwisata Tanah Lot antara Pemerintah Daerah Kabupaten Tabanan dengan Desa Pakraman Beraban belum terjadi keseimbang dalam menentukan hak dan kewajiban dari para pihak. Keseimbangan yang diharapkan Desa Pakraman Beraban dari para pihak dalam perjanjian kerjasama pengelolaan tersebut, berasal dari kesepakatan yang ditentukan sebelumnya dengan memenuhi unsur-unsur keadilan dan kepastian hukum dalam ketentuan KUHPerdata dalam Pasal 1320 dan Pasal 1338. Dimana Pasal 1338 KUHPerdata adalah pilar utama asas kebebasan berkontrak, artinya bebas tidak dalam arti sebenarnya, tapi bebas ada pembatasan atau perkecualian (Intan, 2016).

Perjanjian Kerjasama Pengelolaan Pariwisata Tanah Lot Nomor 358/DPBRB/XI/2011, semua pihak yang terkait sepakat dengan latar belakang (Pasal 1), pengelolaan (Pasal 2), subyek perjanjian (Pasal 3), obyek perjanjian (Pasal 4), organisasi (Pasal 5), jangka waktu (Pasal 6), pendapatan (Pasal 7), biaya (Pasal 8), pembagian hasil (Pasal 9), keadaan memaksa/force majeur (Pasal 10), perjanjian batal (Pasal 11), perselisihan (Pasal 12) dan penutup (Pasal 13).

Pelaksanaan perjanjian kerjasama, hak dan kewajiban dari pengelolaan pariwisata Tanah Lot, belum mencerminkan keadilan yang tercermin pada biaya promosi dan pembagian hasil yang diperoleh Desa Pakraman Beraban yang memiliki tugas untuk mengembangkan dan mengawasi pengelolaan daya tarik wisata Tanah Lot, yang dapat dilihat dalam, Pasal 8 tentang Biaya:

(1) Biaya pengelolaan Daya Tarik Wisata Tanah Lot terdiri dari biaya operasional manajemen dan biaya promosi dan pengembangannya;

(2) Biaya operasional manajemen dianggarkan setiap tahun berdasarkan rapat badan pengelola dan ditetapkan dengan keputusan Ketua Umum Badan Pengelola;

(3) Biaya pengembangan dan biaya promosi ditetapkan sebesar 15\% (lima belas persen) dari penerimaan bruto setelah dikurangi biaya operasional manajemen;

(4) Biaya pengembangan dan biaya promosi sebagaimana dimaksud pada ayat (3) dikelola oleh manajemen operasional dan dipertanggung jawabkan kepada pihak pertama dan pihak kedua;

(5) Perubahan biaya operasional manajemen dilakukan sekurang-kurangnya 6 (enam) bulan sekali berdasarkan rapat badan pengelola;

(6) Penggunaan biaya operasional manajemen sebagaimana dimaksud pada ayat (1) diguna- 
kan untuk gaji/upah pengurus dan/atau karyawan/karyawati manajemen operasional, honor pengurus badan pengelola, biaya rutin dan biaya lain-lain yang sah.

Pasal 9 tentang Pembagian Hasil:

(1) Bahwa dari hasil pendapatan bruto setelah dikurangi dengan biaya-biaya sebagaimana dimaksud dalam Pasal 8, maka para pihak sepakat mengatur hasil pembagiannya sebagai berikut:

(a) Pemerintah Kabupaten Tabanan sebesar $58 \%$ (lima puluh delapan persen);

(b) Desa Pakraman Beraban sebesar 24\% (dua puluh empat persen);

(c) Pura Luhur Tanah Lot sebesar 7,5\% (tujuh koma lima persen);

(d) Pura-pura terkait di kawasan tempat Daya Tarik Wisata Tanah Lot sebesar 4\% (empat persen); dan

(e) Desa Pakraman se-kecamatan Kediri sebesar 6,5\% (enam koma lima persen).

Keseimbangan antara hak dan kewajiban dari para pihak dalam suatu perjanjian, merupakan hal utama sebagai dasar pertimbangan terjadinya perjanjian kerjasama. Pelaksanaan hak dan kewajiban harus terjadi keseimbangan, dari Pasal 9 tentang pembagian hasil belum adanya asas keseimbangan dalam perjanjian, asas keseimbangan bertujuan dalam menghindari kerugian pada prosesnya tidak dapat terlaksana dengan baik sehingga tujuan yang diharapkan tidak dapat tercapai karena asas keseimbangan yang seharusnya sangat berperan dalam menentukan posisi dari para pihak agar dianggap adil dan tidak berat sebelah (Hernoko, 2011).

\section{Kesimpulan}

Perjanjian kerjasama pengelolaan pariwisata Ulun Danu Beratan antara Pemerintah Daerah
Kabupaten Tabanan dengan Desa Pakraman Candi Kuning sudah sesuai dengan syarat sahnya suatu perjanjian dan sesuai dengan Peraturan Pemerintah Nomor 50 Tahun 2007 tentang Tata Cara Pelaksanaan Kerjasama Daerah. Sedangkan bentuk dari perjanjian kerjasama pengelolaan Ulun Danu Beratan antara Pemerintah Daerah Kabupaten Tabanan dengan Desa Pakraman Candi Kuning dibuat dengan bentuk perjanjian dibawah tangan. Perjanjian kerjasama tersebut bertentangan dengan Pasal 179 Ayat (4) Peraturan Menteri dalam Negeri Nomor 19 tahun 2016 tentang Pedoman Pengelolaan Barang Milik Daerah bahwa perjanjian kerjasama harus dibuat dengan Akta Notaris, sehingga dari perjanjian kerjasama tersebut mempunyai kekuatan pembuktian yang kuat apabila terjadi sengketa di pengadilan.

Perjanjian kerjasama pengelolaan pariwisata Ulun Danu Beratan antara Pemerintah Daerah Kabupaten Tabanan dengan Desa Pakraman Candi Kuning sudah/lebih mencerminkan keadilan dibandingkan perjanjian kerjasama pariwisata Tanah Lot, karena dari pembagian hasil dalam perjanjian kerjasama pengelolaan pariwisata Ulun Danu Beratan mencerminkan keadilan bagi pihak Desa Pakraman Candi Kuning selaku pihak yang menjaga kelestarian dan kesucian daerah tujuan wisata Ulun Danu Beratan dan Pura Kahyangan Jagat Ulun Danu Beratan. yang tercermin pada pembagian hasil yang diperoleh Pura Khayangan Jagat Ulun Danu Beratan sebesar 60\% (enam puluh persen) dan Pemerintah Daerah Kabupaten Tabanan memperoleh sebesar 25\% (dua puluh lima persen). Sedangkan dari perjanjian kerjasama pengelolaan pariwisata Tanah Lot, Pemerintah Daerah Kabupaten Tabanan sebesar 58\% (lima puluh delapan persen) dan Desa Pakraman Beraban sebesar 24\% (dua puluh empat persen) yang belum mencerminkan keadilan bagi pihak Desa Pakraman Beraban dalam pembagian hasil dari perjanjian kerjasama pengelolaan pariwisata Tanah Lot. 


\section{Jurnal Cakrawala Hukum}

Vol.8, No.2 Desember 2017: 129-138

\section{DAFTAR PUSTAKA}

Budiono, Herlien. 2006. Asas Keseimbangan bagi Hukum Perjanjian Indonesia-Hukum Perjanjian Berlandaskan Asas-Asas Wigati Indonesia. Citra Aditya Bakti. Bandung.

Griadhi, Wirta. 1977. Peranan Otonomi Desa Adat dalam Pembangunan. Kertha Patrika. Denpasar.

Hernoko, Agus Yudha. 2011. Hukum Perjanjian Asas Proporsionalitas dalam Kontrak Komersil. Kencana Prenada Media Grup. Jakarta.

Hujibers, Theo. 1995. Filsafat Hukum. Kanisius. Yogyakarta.

Marzuki, Peter Madmud. 2007. Penelitian Hukum. Kencana. Jakarta.

Muhamad, Abdulkadir. 2004. Hukum dan Penelitian Hukum. Citra Aditya Bakti. Bandung.

Intan, L. 2016. Akibat pelanggaran oleh notaris terhadap pembuatan akta notariil. Jurnal Cakrawala Hukum, 7(2), 206-215. doi:10.26905/idjch.v7i2.1909.

Purba, Hasim. 2006. Suatu Pedoman Memahami Hukum Ilmu. Cahaya Ilmu. Medan.

Raharjo, Satjipto. 2000. Ilmu Hukum. Citra Aditya Bakti. Bandung.

Situmorang, Viktor M. \& Cormentyna Sitanggang. 1993. Gross Akta dalam Pembuktian dan Ekekusi. Rineka Cipta. Jakarta.

Soekanto, Soerjono \& Sri Mamuji. 2006. Penelitian Hukum Normatif. Raja Grafindo Persada. Jakarta.

Sukarmi. 2008. Cyber Law: Kontrak Elektronik dalam BayangBayang Pelaku Usaha. Pustaka Sutra. Bandung.

Waluyo, Bambang. 2002. Penelitian Hukum dalam Praktek. Sinar Grafika. Jakarta.
Kitab Undang-Undang Hukum Perdata.

Undang-Undang Republik Indonesia Nomor 10 Tahun 2009 tentang Kepariwisataan.

Undang-Undang Republik Indonesia Nomor 6 Tahun 2014 tentang Desa.

Undang-Undang Republik Indonesia Nomor 9 Tahun 2015 tentang Pemerintah Daerah.

Peraturan Pemerintah Republik Indonesia Nomor 50 Tahun 2007 tentang Tata Cara Pelaksanaan Kerjasama Daerah.

Peraturan Menteri Dalam Negeri Republik Indonesia Nomor 19 Tahun 2016 tentang Pedoman Pengelolaan Barang Milik Daerah.

Peraturan Daerah Provinsi Bali Nomor 3 Tahun 2001 tentang Desa Pakraman.

Peraturan Daerah Kabupaten Tabanan Nomor 9 Tahun 2016 tentang Rencana Pembangunan Jangka Menengah Daerah Semesta Berencana Kabupaten Tabanan Tahun 2016-2021.

Perjanjian Kerjasama Pengelolaan Daya Tarik Wisata Antara Pemerintah Daerah Kabupaten Tabanan Dengan Satakan Ulun Danu Beratan dan PT. Rekreasi Air Beratan Indah Nomor: 2 tahun 2011.

Perjanjian Kerjasama Pengelolaan Daya Tarik Wisata Antara Pemerintah Daerah Kabupaten Tabanan Dengan Desa Pakraman Beraban Kecamatan Kediri Nomor 358/ DPBRB/ 2011.

\section{How to cite:}

Gunawan, I G. P. A. 2017. Analisis Perjanjian Kerjasama Pengelolaan Pariwisata Ulun Danu Beratan Desa Pakraman Candi Kuning Kabupaten Tabanan. Jurnal Cakrawalah Hukum, 8(2). 